\title{
Student online marketplace for university community
}

\author{
Mohd Fahmi Ismail, Maslina Abdul Aziz, Fatin Nur Syuhada Mohd Nor, \\ Syaripah Ruzaini Syed Aris, Suzana Zambri \\ Faculty of Computer and Mathematical Sciences, UiTM Shah Alam, Selangor, Malaysia
}

\begin{tabular}{l}
\hline \hline Article Info \\
\hline Article history: \\
Received Sep 18, 2019 \\
Revised Nov 22, 2020 \\
Accepted Dec 29, 2020 \\
\hline
\end{tabular}

\section{Keywords:}

Business

Entrepreneurs

Marketplace

Social media

Start-up

\begin{abstract}
This research presents student online marketplace for university community. In this study, we identify current issues faced by university students while starting their business. Based on the preliminary investigation, it was found out that there are a number of students doing part-time jobs and doing business to support their living expenses. There are varieties of businesses and services offered among students especially students staying in colleges. However, the main problem faced by students either as the buyer or the seller is there is no business platform to promote their products or services. Al-so, there is a lack of information regarding the business or services since most communications are done through $\mathrm{h}$ instant messaging apps such as WhatsApp and social media. By having a student online marketplace, the exchange of goods and services take place by having buyers and sellers being in contact with one another. This student online marketplace also helps small businesses to boost their sales, encourage new business start-up and inspire students who have business idea to help them to kick-start their business. Students are able to perform their business in a safe and secure environment.
\end{abstract}

Copyright @ 2020 Institute of Advanced Engineering and Science. All rights reserved.

\section{Corresponding Author:}

Mohd Fahmi Ismail,

Faculty of Computer and Mathematical Sciences,

UiTM Shah Alam, Selangor, Malaysia.

Email: 1sntl@ccu.edu.tw

\section{INTRODUCTION}

Online marketplace is an e-commerce or platform where sellers can provide their products or services and the process of transaction between sellers and buyers can occur by the marketplace operator. One of the purposes of Malaysia Education Blue-print 2015-2025 (Higher Education) is to deliver a Holistic Entrepreneurial and Balanced Graduates with producing work makers who are adjusted nationals with an entrepreneurial outlook rather than job seekers. Because of this initiative, this research focuses on entrepreneurship level among university students specifically University Technology Mara (UiTM) students in Shah Alam by proposing an online marketplace for it. From the initial findings, there are a number of UiTM students own a business and doing part time business. Some of them owns a family business, some sell beauty products, mobile phone top-up. Some students provide services based on their personal skill, for example fixing computers, provide haircut and personal shopper. Some students who have their own transport, they work as food delivery person or they become Grab Car driver. These students usually do these businesses as part-time job for extra pocket money. This is the real situation faced by the UiTM students since they do not have a proper business platform to commercialize their products or promote their services. For some students that are currently running a business, they commercialize their products or services to their friends via word of mouth. There are also some students using social networking such as Facebook and Instagram as a medium to run the business. This kind of business only target a specific group of customers only. Therefore, a right e-marketplace platform that specifically for students to commercialize their products or services to expands their business is proposed. The market-place is to help UiTM students that have a lack of knowledge to begin the venture into entrepreneurship field. 
An online marketplace is a sort of electronic business site where products or ser-vices is given by various third parties. All transaction that happened in online marketplace was processes by the marketplace operator. Online marketplaces are the essential sort of multi-channel e-commerce; it also can be an approach smooth the production process. With buyers on one side, and third-party merchants on the other, online marketplaces are a two-sided platform of substantial economic importance [1]. Online marketplace cannot be formed without trust from buyers and sellers. Buyers need to trust that sellers are precisely portraying products or services, and satisfying transactions as guaranteed [2]. The attitudes and intentions towards using online shopping in Malaysia is still low but increasing year by year. This is proven by the study done by MCMC that e-commerce users have increased to $48.8 \%$ in 2017 compared $35.3 \%$ in previous year [3]. Consumers in Malaysia prefer to go the physical stores, lack of confidence and skills, as well as security and privacy concern. Therefore, it is undeniable that there are some substitution effects between physical and virtual markets among users [4].

\subsection{Online marketplace business model}

Business model is a method of doing business where company can apply to generate revenue to sustain itself. Business model comes from a subset of a business plan and business case. Business model is a term that only comes into the management literature recently but increasingly attracting attention within research on e-business [5]. A business model is vital to a firm as a result of its directly relevant to the company's market looks such as products and services, potential customers, and sales channel. The business model tells a logical story explaining who your customers are, what they value, and how you'll make money providing them that value [6]. present a list of business model components including customer value, scope, price, revenue sources, connected activities, implementation, capabilities, and sustainability [5]. There are three main components include in online marketplace business model such as value proposition, valuegenerating or adding process, and value appropriation. The value proposition is referring to the utility that customers can get from the information, products, and services [7]. The value-generating or adding process refers to the transformation method that takes place inside online marketplace as they take less valuable offer inputs and switch them into additional valuable offer outputs. The value appropriation refers to the business model itself that can retain from collaborating at a selected stage within the supply chain. There is no single comprehensive taxonomy for e-business model classification. However, the propose e-business model proposed comply with different models with eight categories: brokerage, advertising, infomediary, merchant, affiliate, community, subscription, and utility [8].

\subsection{Features commonly applied in online marketplace}

The analysis study is comparing some functionalities of few marketplaces. The functionalities of marketplaces were identified in order to describe variations in the features of the existing marketplace in terms of ease of use and compatibility with the technology [9]. These features as shown in Table 1.

Table 1. Common marketplace features

\begin{tabular}{|c|c|}
\hline Features & Description \\
\hline $\begin{array}{l}\text { Account } \\
\text { Administration }\end{array}$ & $\begin{array}{l}\text { This feature is including the registration and also login account of marketplace. Sometimes users use their social } \\
\text { networking accounts such Facebook to register. }\end{array}$ \\
\hline $\begin{array}{l}\text { Categorization and } \\
\text { Search }\end{array}$ & $\begin{array}{l}\text { Product categorization in marketplace is very important and the search feature is used within the category } \\
\text { parameter. }\end{array}$ \\
\hline Company & company profile should be updated and available for viewing. This will increase buyer's confidence level. \\
\hline Information & The company profile should also include information on \\
\hline View Item. & $\begin{array}{l}\text { A sneak peek features with various types of image manipulation included zoom features must be provided in } \\
\text { marketplace. Items details specification such as description, prices, ratings, and statistics of item sold must be available. }\end{array}$ \\
\hline Booking Process & $\begin{array}{l}\text { Pre-order for booking and efficient shopping cart is essential for the booking process. The information including } \\
\text { total expenditure, shipping cost, taxes, or discount must be included in the transaction details. }\end{array}$ \\
\hline Payment Process & \\
\hline Delivery Process & $\begin{array}{l}\text { Flexibility of delivery service is needed in order to increase customer's satisfaction. However, postal address } \\
\text { can be different for each ordered item. It is an important feature to estimate shipping cost during the process of } \\
\text { filling out the address. }\end{array}$ \\
\hline Seller's Website & $\begin{array}{l}\text { The seller's website needs to contain important information such as the store name, logo and the availability of } \\
\text { the store. But what is most important things is setting the features products in the physical store. }\end{array}$ \\
\hline 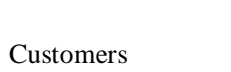 & $\begin{array}{l}\text { ure allows the customers to see their transaction progress, transaction status, payment confirmation, } \\
\text { ansactions history. Other than that, buyers get to change their profile or add a list of addresses for item }\end{array}$ \\
\hline Dashboard & $\begin{array}{l}\text { pping. Other features that can add into customer's dashboard such as wish list, number of points, incoming } \\
\text { ssages, comments and reviews. }\end{array}$ \\
\hline Seller's Dashboard & $\begin{array}{l}\text { This feature allows sellers to view orders progress, order status, delivery confirmation and status, product } \\
\text { statistics and the order history. }\end{array}$ \\
\hline Customer S & $\begin{array}{l}\text { Customer's loyalty to the marketplace can be increased by having this feature that includes interaction and } \\
\text { prompt response with buyers. }\end{array}$ \\
\hline
\end{tabular}




\begin{tabular}{ll}
\hline Features & Description \\
\hline Social Media & $\begin{array}{l}\text { The social media is important in order to maintain a communication with buyers as well as customer service, } \\
\text { and promoting stores, spreading promotion/ news / advertisement or sharing shopping tips. }\end{array}$ \\
\hline
\end{tabular}

\subsection{Popular marketplace}

The internet has changed the way business is running and offer an opportunities and standards to buyers and sellers. The result form the survey to UiTM students shows that, most students are doing their business using popular online marketplace available such as Mudah.my and on UiTM marketplace called the Virtual Mall (UiTMVmall) [10]. This section compares some of the existing online marketplaces used by the students to sell their products.

Figure 1 shows that Lazada is the most famous online marketplace among students with $71 \%$, and there a few online marketplaces that are not use by students to purchase at their such as 11 street, Lelong.com, Instagram, One Mall, Facebook, and Zalora, each of them only 1.6\%. One of the findings from this survey is, the main factor to choose a marketplace to do business is the ease of use. They all agreed that Lazada, Mudah.my, and Shopee have the best features which is less hassle in registration process, easy to understand and use. Besides that, Lazada always provide vouchers and promotions that attract the students to always visit it.

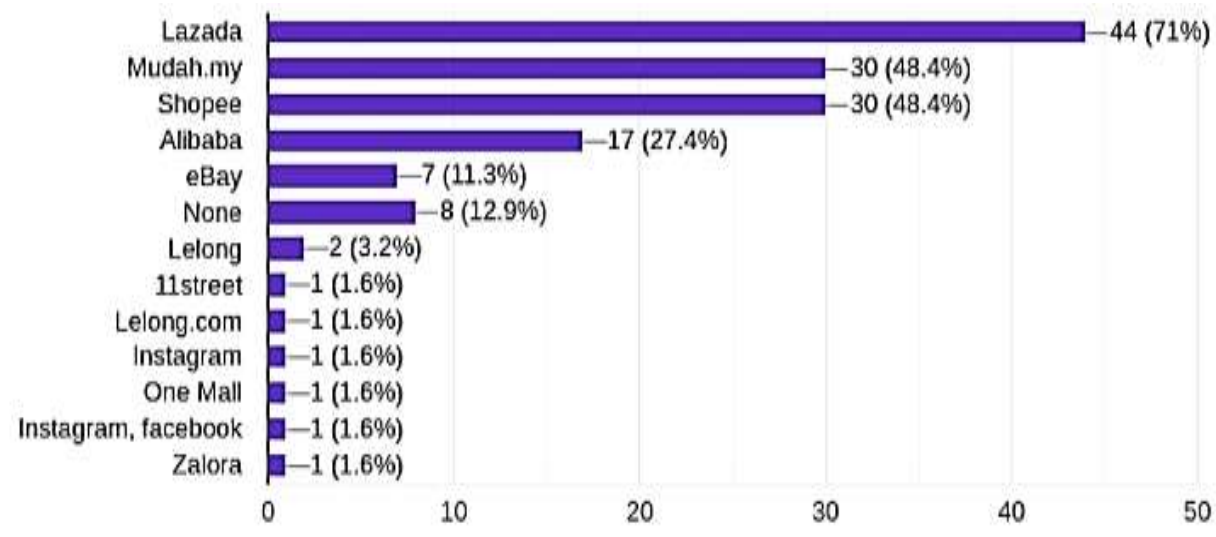

Figure 1. Popular online marketplace among UiTM students doing business

\section{4. lazada}

Lazada is a one of the most popular online marketplaces where people can buy and sell a wide variety of goods, products, and services based on different categories such as real estate, automotive, careers, business products and services, and many more [11]. The service allows anyone either individuals or business groups to buy and sell in their region conveniently, without the need for a physical shop or a registered company. Lazada is famous due to its reputation and trust in people. It attracts high traffic of new customers due to its popularity. However, one of the main concerns when setting up a shop on Lazada is in the form of marketplace commission fee. Since the students do not have much capital, this is the main drawbacks of using Lazada.

\subsection{UiTM virtual mall (UiTMVmall)}

UiTMVmall is a marketplace model that allowed third-party retailers which is UiTM students to sell their products through this site. Buyers can search an item by categories that provided in this marketplace and add to cart if they interest to buy that items. The transactions that occur in this marketplace is an online backing account and FPX payment method also was accepted. However, this marketplace is lack of maintenance and it is not so popular among UiTM community. It is very important to create awareness of the importance of accessibility and usability criteria focusing on how user interacts with a website [12-16].

Both of these marketplaces offer a lot of business opportunities for the students. However, there are some problems that are unavoidable. Some of the student's problem is unable to find an online platform that suits existing student's business. It is also difficult for sellers and buyers to exchange product or service in a secured and safe environment. Even though, there are already e-marketplace that was created for UiTM students which is UiTM Virtual Mall (V-Mall), it was not exclusive for UiTM community. There are also other big businesses and vendors that sells at the V-Mall. This makes the V-Mall very competitive and it is 
not suitable for students who are just starting their business and services. This situation is also applied to other marketplaces such as Mudah.my, Shopee.com and Lazada.com. Besides that, there are fees to pay in some of the marketplaces.

Based on the interviews to the students who owns a business, there are few problems identified. One of the of problems is they are unable to collaborate with each other (student-to -student). Students always have a communication problem with their customers. There are also students that have a problem with the customers that does not pay on time or does not pay at all. Therefore, is a need for a e-marketplace for a customized UiTM community that will focus on entrepreneurship level among university students [17-18]. This will help students to commercialize their business and generate side income in a safe and secured manner.

\section{RESEARCH AND FINDINGS}

Questionnaire and interview were used for the data collection for this project. Questionnaire was distributed among UiTM students to understand about the sce-nario of UiTM students running the business as well as to identify the problems that faced by them. A set of questionnaires was distributed among UiTM students in 23 September 2018 by using Google Form. There are about 62 respondents participated. The respond to the survey was very positive $\mathrm{d}$ because all respondents gives a good cooperation and give a quality answer that help the author to gain an idea to improve the current implementation. Next, the interview session was conducted between two types of stakeholders; the staffs and students. The purpose to do the interview was to understand how they run a business and identify the problems they faced by them during the business.

Based on the result shown in Figure 2, there are about $73.5 \%$ of students were interested to start their own business. Even though they have no business idea, but they are very keen about it. The $26.5 \%$ students are not interested in doing business. Based on the result, we also found out that among the main reasons students are not interested to do business are time constraint and lack of business knowledge.

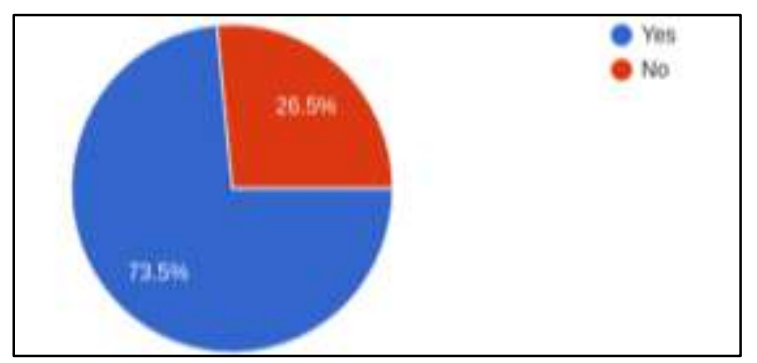

Figure 2. Students who interest to start a business

Figure 3 shows that $69.2 \%$ of the students do not start a business due to lack of time. Other major reasons are lack of knowledge or skills, inadequate capital, and information overloaded. We can conclude that mostly students are unable to start their own business due to poor planning and lack of knowledge. They are also in-competent to balance their time between managing a business and study. In order to rectify these issues, UiTM have set up several initiatives to help students. Malaysian Academy of SME \& Entrepreneurship Development (MASMED) in UiTM is ressponsible to encourage and nurture the students to be entrepreneurs. MASMED collaborate with Small and Medium Enterprise (SME), Malaysia Digital Economy Corporation (MDEC), Malaysian Technology Development Corporation (MTDC), TERAJU, Majlis Amanah Rakyat (MARA) and government agencies. Among the programs offered to the students are Graduate Accelerator Entrepreneurship (Grace Lab), MASMED Young Entrepreneur (MyENT), MASMEDUiTM Social Entrepre-neurship Challenge, Online Business Springboard and others. These programs and certification courses are catered for students who are serious in starting their busi-ness and in a way to boost the graduate employability rate.

Based on the questionnaire result Figure 4, among the popular business among students are food and beverages with $61.1 \%$, fashion with $38.9 \%$, electronic accesso-ries with $30.6 \%$ and beauty products with $27.8 \%$. Meanwhile, the most popular ser-vices offered by students is computer repair, mobile reload, hair and make-up and printing services. There is a much higher demand for food business. However, some students find it very difficult to do this business because they do not have the proper equipment and material for food handling. 


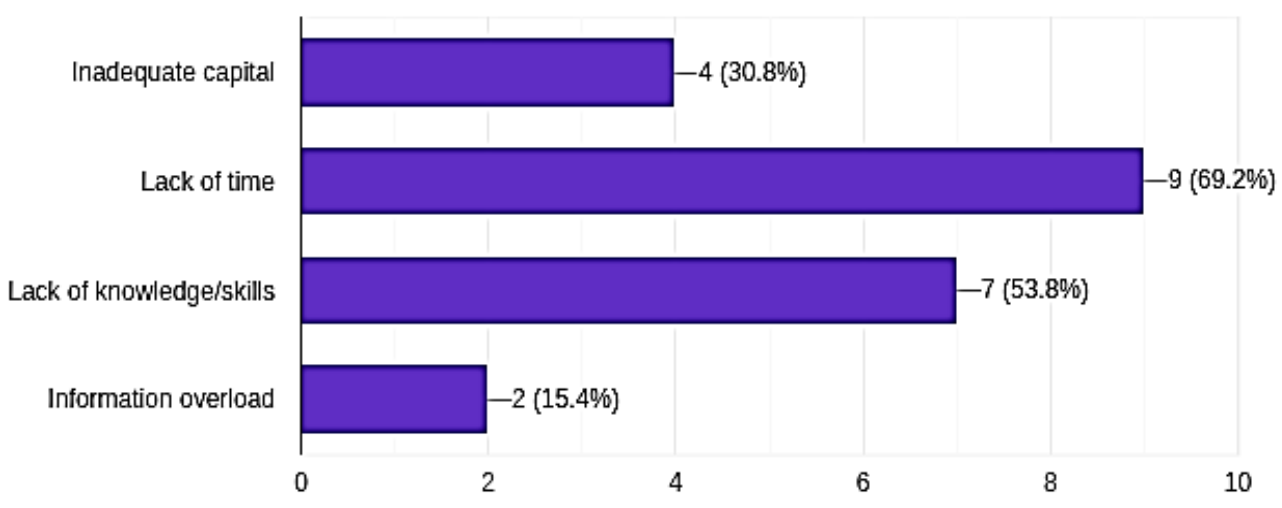

Figure 3. Barriers to start a business

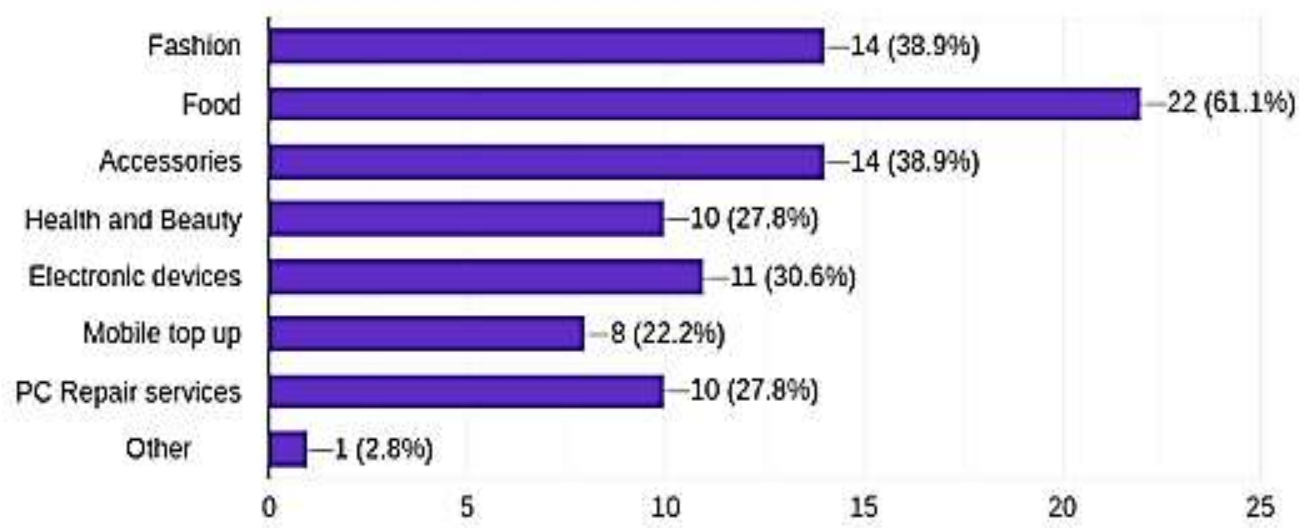

Figure 4. Type of business

Another survey was done to 60 students who have already established their own business Figure 5. These students are not just from business studies, most of them are from diverse background studies such as Computer Science, Architectural, Engineering and Law. Some students have started in their early stage of their undergraduate and some students are continuing the family business. Among the types of business, they are running are depicted in the pie chart below. Based on the findings, the food and beverages business are still in the lead. Among the types of food they sell are chips, chocolate snacks, cookies and cakes. The other popular business is clothing with majority of them selling hijab, scarf and specifically "Muslimah" fashion. Besides that, there are also some students who own service business such as car rental and online wedding invitation system.

As part of the initiatives to encourage UiTM students to venture into entrepreneurship, a student marketplace was developed to support the UiTM community specifically to do business. It helps to promote the product and services [19-21]. Based on the survey, students are very interested with the online marketplace that are designed specifically for them. This will help them to make sale and purchase between them without worrying that they may be cheated. This marketplace offers a platform for new start-ups business to do their business without any hassle or charges. This marketplace was designed based on the research done on different types existing marketplaces [22-23].

Figure 6 below is the use case diagram for the Student Online Marketplace. There are 9 main functions. There are also 3 actors involved. A student needs to register and log in before using the system. The system will automatically identify the student based on the student Id. Only existing student in the UiTM community is al-lowed to use this system. Any transactions in the system will be monitored by some admin personnel. Any misconduct will be reported and the admin has the rights to block any user. As mentioned before, this marketplace is still at the prototype stage. There are some features and functions that need to be added and refined. The feed-back from the stakeholders will be taken into consideration for improvements. 
From the use case diagram, the prototype Students Online Marketplace is de-signed and developed. The author used the Laravel framework. Laravel framework is chosen due to its environment for web site developments, security, and maintenance [24-25]. Also, the ability to reuse the system component from the prototype into the development of system. The system has complete features and functions based on the requirement that get from the stakeholders. The system is developed by using Visual Studio Code as a software, and MySQL as a database for the system. After finished developing the prototype, the author conducts a meeting session with the stakeholders to validate the Students Online Marketplace. This method will be repeated until the stakeholders are satisfied with the prototype. The Students Online Marketplace not only helping students to run their business, creates new business and at the same time creates new jobs.

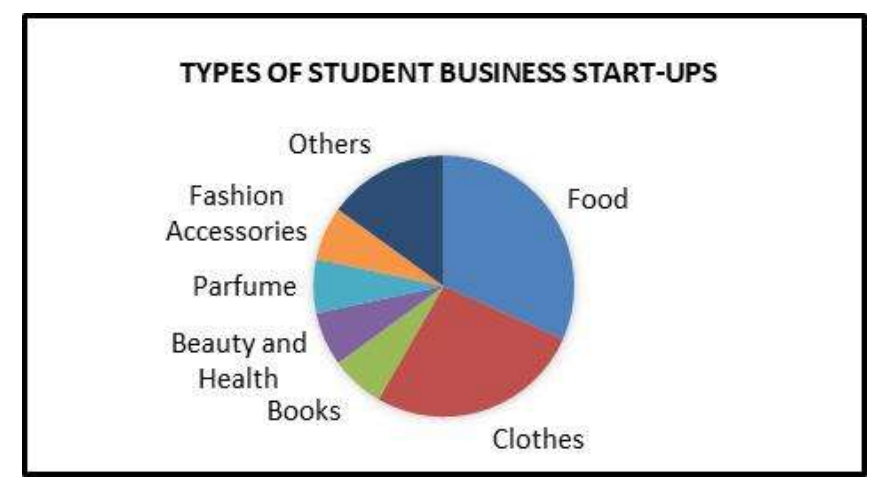

Figure 5. Types of business start-up

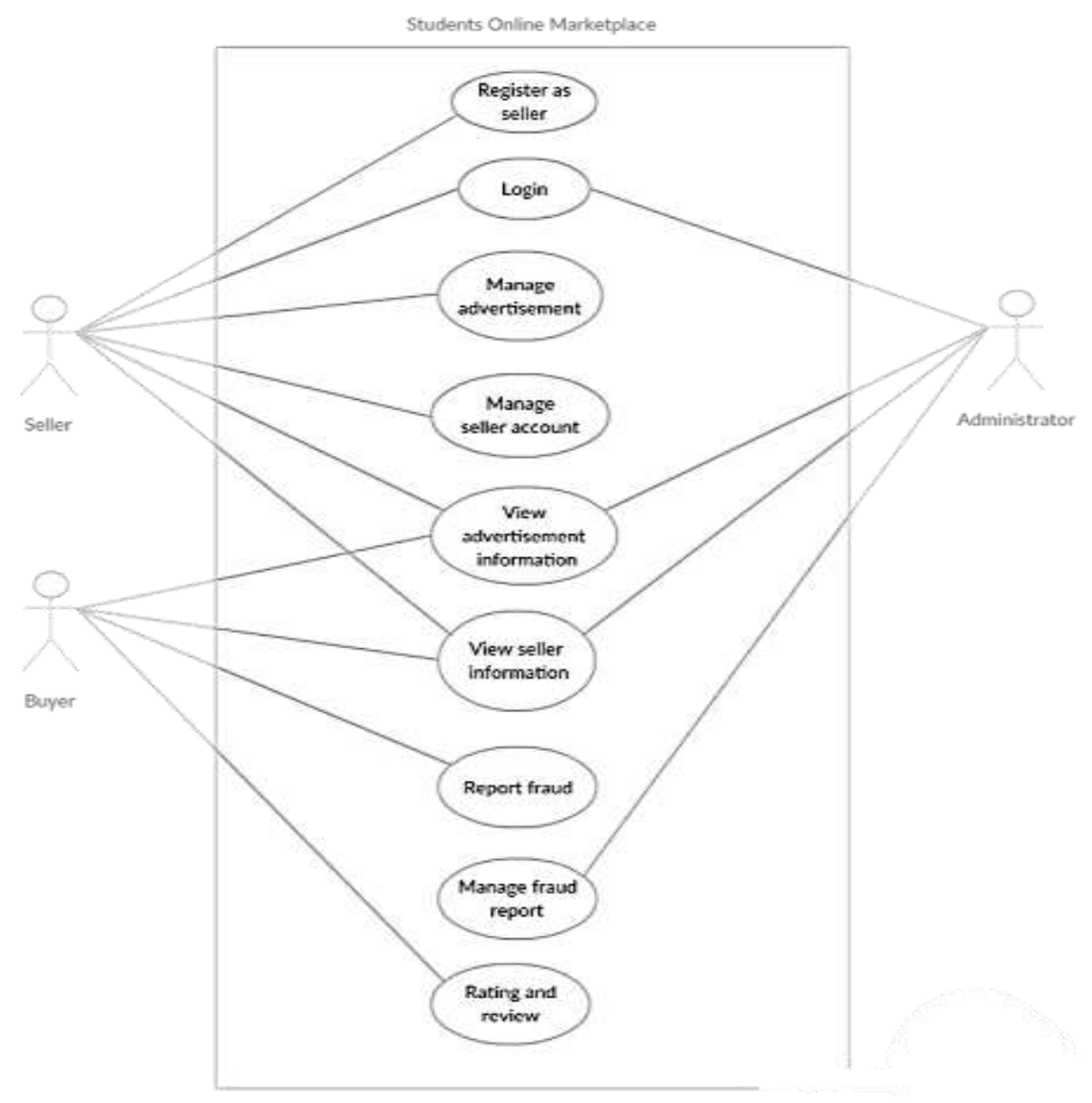

Figure 6. UiTM student online marketplace use case diagram 


\section{CONCLUSION}

This paper presents the student online marketplace for university community. This online marketplace helps students to perform their business among the university community in a safe and trusted way. There are a number of students doing part time business. Most students sell their products using popular marketplaces such as Shopee. They use social media such as Instagram to promote their services. This has caused a lot of problems in terms of safety since there is no specific platform for it. The significance of this project is for UiTM students who already have business or new business start-ups to expand, promote, and commercialize their business. This student online marketplace will become the online platform that students can use and practice their entrepreneurial skills. This marketplace will centralize all the business activities among students together with the social networking to connect product/service and boost up their sales. In the future, this marketplace will available for all UiTM community by engaging more students from different campuses all over Malaysia. It will be a start-up point for students to start off their entrepreneurial journey.

\section{ACKNOWLEDGEMENTS}

The authors gratefully acknowledge Faculty of Computer Science and Mathematics, Universiti Teknologi Mara (UiTM), Malaysia for all the supports for this research. Special thanks to Mr Nurul Hafez Abd Halil from Malaysian Academy of SME \& Entrepreneurship Development (MASMED) of UiTM for all the cooperation in completing this project.

\section{REFERENCES}

[1] J. -C. Rochet, and J. Tirole, "Platform competition in two-sided markets," Journal of the european economic association, vol. 1, no. 4, pp. 990-1029, 2003.

[2] M. Luca, "Designing online marketplaces: Trust and reputation mechanisms," Innovation Policy and the Economy, vol. 17, no. 1. pp. 77-93, 2017.

[3] K. W. Lee, M-T. Tsai, and M. C. L. Lanting, "From marketplace to marketspace: Investigating the consumer switch to online banking," Electronic Commerce Research and Applications, vol. 10, no. 1, pp. 115-125, 2011.

[4] MMC Homepage, https://www.mcmc.gov.my/skmmgovmy/media/General/pdf/MCMC-Internet-Users-Survey2017, pdf, last accessed 2019/3/3.

[5] A. Afuah, and C. L. Tucci, "Internet business models and strategies: Text and cases," McGraw-Hill, Inc., vol. 2. 2003

[6] M. Yunus, "Social business entrepreneurs are the solution," The Future Makers. Routledge, pp. 219-225, 2017.

[7] M. W. Johnson, C. M. Christensen, and H. Kagermann, "Reinventing your business model," Harvard business review, vol. 86, no. 12 pp. 57-68, 2008.

[8] N. Janom, and M. S. Zakaria, "B2B e-commerce: Frameworks for e-readiness assessment," International Symposium on Information Technology, vol. 1, pp. 1-8, 2008.

[9] M. A. Rappa, "The utility business model and the future of computing services," IBM systems journal, vol. 43, no. 1, pp. 32-42, 2004.

[10] VMall website https://www.uitmvmall.com. Accessed on 2 February 2018

[11] Lazada Website https://www.lazada.com.my. Accessed on 2 February 2018

[12] D. Sasongko, R. Ferdiana, and R. Hartanto, "The development of digital library user interface by using responsive web design and user experience," Indonesian Journal of Electrical Engineering and Computer Science, vol. 4, no. 1, pp. 195-202, 2016.

[13] A. A. Syuhada, and W. Gambett, "Online marketplace for Indonesian micro small and medium enterprises based on social media," Procedia Technology, vol. 11, pp. 446-454, 2013.

[14] M. A. Aziz, W. A. R. W. M. Isa, and N. Nordin, "Assessing the accessibility and usability of Malaysia Higher Education Website," International Conference on User Science and Engineering, pp. 203-208, 2010.

[15] G. Saibaba, and S. P. Vaidya, "Developing an userfriendly online shopping web-Site," Indonesian Journal of Electrical Engineering and Computer Science, vol. 12, no. 3, pp. 1126-1131, 2018.

[16] W. A. R. W. M. Isa, M. A. Aziz, and M. R. B. A. Razak, "Evaluating the accessibility of Small and Medium Enterprise (SME) websites in Malaysia," International Conference on User Science and Engineering (i-USEr), pp. 135140, 2011.

[17] G. Hägg, and A. Kurczewska, "Who is the student entrepreneur? Understanding the emergent adult through the pedagogy and andragogy interplay," Journal of Small Business Management, vol. 57, pp. 130-147, 2019.

[18] M. Wright, D. S. Siegel, and P. Mustar, "An emerging ecosystem for student start-ups," The Journal of Technology Transfer, vol. 42, no. 4, pp. 909-922, 2017.

[19] W. A. R. W. M. Isa, N. L. Md Noor, and S. Mehad, "Culture design of information architecture for B2C ecommerce websites," International Conference on Human Centered Design, vol. 5619, pp. 805-814, 2009.

[20] N. Janom, and M. S. Zakaria, "B2B e-commerce readiness assessment indicators based on the critical success factors, " International Conference on Electrical Engineering and Informatics, vol. 2, pp. 405-411, 2009.

[21] H. L. Rahim, and R. Chik, "Graduate entrepreneurs creation: A case of Universiti Teknologi MARA, Malaysia," Australian Journal of Basic and Applied Sciences, vol. 8, no. 23, pp. 15-20, 2014. 
[22] C. Perera, C. H. Liu, and S. Jayawardena, "The emerging internet of things marketplace from an industrial perspective: A survey," IEEE Transactions on Emerging Topics in Computing, vol. 3, no.4, pp. 585-598, 2015.

[23] S. Wang, N. P. Archer, and W. Zheng, "An exploratory study of electronic marketplace adoption: A multiple perspective view," Electronic Markets, vol. 16, no. 4, pp. 337-348, 2006.

[24] "Laravel-The PHP Framework for Web Artisans: Website: https://laravel.com. Accessed on 19 August 2018.

[25] M. Laaziri, K. Benmoussa, S. Khoulji, and M. L. Kerkeb, "A Comparative study of PHP frameworks performance," Procedia Manufacturing, vol. 32, pp. 864-871, 2019.

\section{BIOGRAPHIES OF AUTHORS}
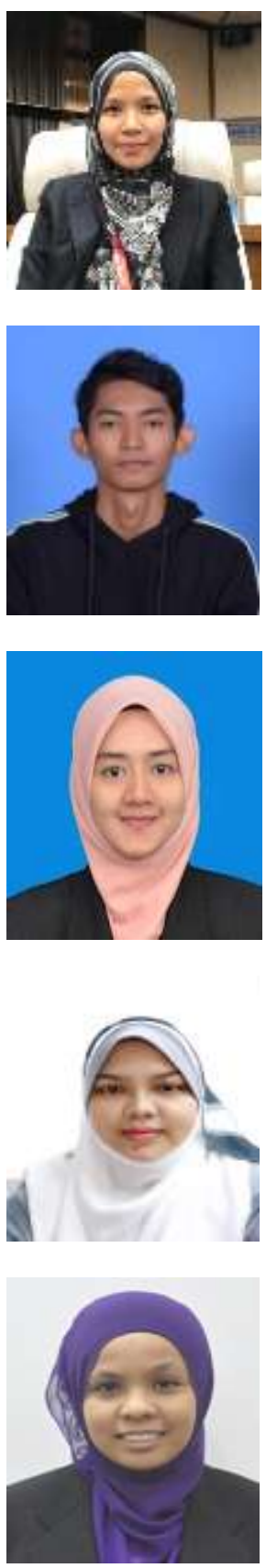

Dr. Maslina Abdul Aziz is a Senior Lecturer at Universiti Teknologi MARA, Malaysia. She holds a M(E) in Software from University of Queensland, Australia. She also obtained a PhD from Deakin University, Australia. She worked as an Executive at Multimedia Development Corporation (MDEC) in Cyberjaya. Her research interests are Systems and Software / Systems Engineering and Industrial Informatics. She is a member of International Association of Engineers (IAENG) and a Professional Technologists from Malaysia Board of Technologists (MBOT). Her research area also includes E-commerce as she is certified as Alibaba Master Trainer and Google Ads.

Mohd Fahmi Bin Ismail has a degree of Bachelor of Information System Engineering, Faculty of Computer and Mathematical Sciences, Universiti Teknologi Mara. He was an intern at INFOPRO SDN BHD as a developer. During his internship, he was assigned into Research and Development (R\&D) team to do a research towards technologies that was related to the banking and financial. He also involved in team project just to do a proof of concept (POC) which is to demonstrate the functionality and to verify a certain concept or theory that can be achieved in development. Currently, he works as a system engineer at the same company. He was placed into Development and Support team in Loan Department.

Fatin Nur Syuhada Mohd Nor is a Java developer with 2 years' experience in programming language and currently works for a service provider company. The company develop and operate an electronic procurement system for the Government of Malaysia. She holds a Bsc IT in Business Computing from Universiti Teknologi MARA, Selangor. She is interested to gain more skill in programming and management skills.

Dr. Syaripah Ruzaini Syed Aris is a currently Postgraduate Program Coordinator at Center of Information System Studies, Faculty of Computer and Mathematical Sciences, Universiti Teknologi MARA. Research interest include IT Management, Risk Management, Strategic Planning and Crowdsourcing. She provides consultation services related to Strategic Planning and Crowdsourcing. She also enjoys giving training to area related to crowdsourcing.

Suzana Zambri is a lecturer at Universiti Teknologi MARA. She has deep interest in digital entrepreneurship where she has published research papers, provided consulting service for government agency, organized entrepreneurship projects with communities, holds master trainer certification in Alibaba and Google Ads, mentored students in embarking their first online businesses and became rapporteur in conventions $\mathrm{n}$ workshops in the area. She is also interested in technology as tools in learning where students under her supervision developed a number of web-based and mobile applications using virtual and augmented reality that support learning processes for children and adults. Currently she is the Head of Corporate Communication for Faculty of Computer and Mathematical Sciences where she applies her digital marketing skills to branding the faculty's image and increase its visibility. 